\title{
Economic and Legal Aspects of Cryptocurrency Usage in Russia
}

\author{
Ekaterina Dorokhova \\ Harvard Law School, Cambridge, MA 02138, United States \\ edorokhova@1lm19.law.harvard.edu \\ Elena Dorokhova \\ Institute of Economics and Management, Belgorod State \\ National Research University, Belgorod 308015, Russia \\ dorokhova@bsu.edu.ru
}

\author{
Tatyana Belykh \\ Institute of Economics and Management, Belgorod State \\ National Research University, Belgorod 308015, Russia \\ belikh@bsu.edu.ru \\ Galina Koren'kova \\ ${ }^{4}$ Institute of Engineering and Construction, Belgorod State \\ Technological University named after V.G. Shukhov, Belgorod \\ 308012, Russia \\ g-korenkova@yandex.ru
}

\begin{abstract}
Cryptocurrencies have become an intrinsic part of our new reality. At the same time legal nature and preferred regulatory regime for cryptocurrencies have long been a hot topic. The treatment and legal status of cryptocurrencies varies across different jurisdictions, from categorization as a means of payment or asset, to a complete ban. This article analyzes the new Russian legislation on cryptocurrency and tokens adopted this summer which is aimed at concluding the uncertainty regarding the legal nature and regulatory regime of cryptocurrency and tokens in Russia. The new legislation outlaws the use of cryptocurrency and tokens as means of payment and sets in stone their status as assets. It also imposes additional liabilities on the cryptocurrency holders, including obligation to declare cryptocurrency to the tax authorities which may result in such cryptocurrency being subject to Russian tax. We further make an overview and analyze the implications of the recently imposed tax and criminal liability for failure to report cryptocurrency transactions and failure to include profits from operations with cryptocurrencies into the taxable income, and administrative liability for accepting cryptocurrency or tokens as means of payment for goods or services. Finally, we consider the place of Russia in the global cryptomarket, outlook for cryptocurrencies, recent Russian precedent transactions involving cryptocurrencies and the Central Bank experiment with the Russian ruble.
\end{abstract}

Keywords - cryptocurrency, Bitcoin, blockchain, digital currency, digital financial assets, tokens, digital ruble.

\section{INTRODUCTION}

Over the past decade blockchain technology and cryptocurrencies have transformed the world economy and opened the market for new opportunities. As the use of cryptocurrencies in various businesses and contexts becomes increasingly widespread, it is clear that legislators and regulators will play a key role in determining the development of the cryptocurrency in the future. While the states have their concerns about lack of transparency and of the controlling centre pertaining to the cryptocurrency (which can result in cryptocurrency being is used as consideration for illegal transactions and money laundering), imposition of harsh restrictions on issuance and transactions with cryptocurrency may result in the transfer of legit projects and investments into jurisdictions with more favourable cryptocurrency regimes. Similar to their foreign counterparts, Russian legislators and regulators are now facing very real challenges and questions on how to categorize and regulate cryptocurrencies against the backdrop of a globalized world. We are now standing at the edge of adoption and implementation of the new regulatory regime which will determine the development of the cryptoindustry in Russia for the foreseeable future. This article analyses the recent changes to the Russian legislation and the legislative initiatives relating to cryptocurrency and digital financial assets and discusses their possible economic implications for the Russian business. To this end, we have used methods of analysis, systematization, comparison and the method of graphical display of data, which made it possible to ensure the implementation of the goal and objectives of this research.

\section{CHANGE OF THE REGULATORY LANDSCAPE AND NEW LEGAL REALITY}

\section{a. You can own but you can not pay}

After a 2.5-year review by the state Duma, in summer President Putin signed into law a bill "On digital financial assets (the "DFA"), Cryptocurrency and Making Changes to Certain Legislative Acts of the Russian Federation" [12] (the "Law") effective from 1 January 2021. Under the Law the DFA is defined as digital rights, including receivables, rights under the issuable securities, participation rights in the capital of a non-public company, and right to demand transfer of the issuable securities (such issue, accounting and circulation of which are only possible through making or changing relevant records in the information system based on the blockchain technology and other information systems) [12].

Although the Law does not differentiate between tokens of different functionality and nature, it follows from the definition that it refers specifically to security tokens, i.e. digital analogue of securities attesting to ownership and giving its holders right to exercise their investment rights Copyright () 2021 The Authors. Published by Atlantis Press International B.V. 
(right of ownership of the security, participation rights, rights to dividends etc.). It seems that the legislator did not have in mind the other type of coins - utility tokens - that entitle the holder to a definable benefit, service or goods. However, such tokens have already been issued long before the enactment of the Law, with the most prominent example being the biggest Russian state bank "Sberbank" issuing "Spasibo" bonuses. [20]

Very few provisions of the Law are devoted specifically to the cryptocurrency. The Law defines cryptocurrency as a set of electronic data (digital code or designation) in the information system, which are offered and/or can be accepted as a means of payment. Such currency can not be a monetary unit of the Russian Federation, a monetary unit of a foreign state and/or an international monetary or unit of account, and/or as an investment, and in respect of which there is no person obligated to each owner of such electronic data [20]. While such definition certainly makes it crystal clear that cryptocurrency is legal, it does not answer the question of whether cryptocurrency is an asset or means of payment. Article 14 of the Law clarifies that it is the former and prohibits Russian entities, branches of foreign companies set up on the territory of Russia and Russian residents (individuals present in Russia 183 and more days within 12 consecutive months) to accept cryptocurrency as means of payment for goods and services [20]. Moreover, the new draft bills on the liability for breach of the Law already expressly state that cryptocurrency is an asset (see item 3 below).

This is not the most liberal approach the legislator could have taken, e.g. a number of countries - Japan, Sweden and Philippines - accept cryptocurrency as means of payment. However, Russian authorities including Central Bank and the Ministry of Finance, have raised multiple concerns about the use of such "money surrogates" as cryptocurrency which could result in facilitation of money laundering and financing of terrorism [6]. Against this backdrop, it is fortunate that cryptocurrency was not completely banned like it was in Romania, Ecuador and Nigeria. Hence, Russian legislator made Solomon's decision by assigning cryptocurrency and tokens the status of the asset which is a view that is shared by a number of jurisdictions, including Canada, the Netherlands, Brazil, Mexico, Israel and others (see Table 1).

Given that the Law declares cryptocurrencies as illegal means of payment, it also prohibits any dissemination of information on cryptocurrencies as means of payment [10]. Finally, cryptocurrencies will now need to be declared to the tax authorities [10] and we can thus expect that the declared amounts of the cryptocurrencies will be subject to Russian tax.

\section{b. New questions}

Are provisions on the tax reporting even feasible? Will Russian miners or owners of the cryptocurrency want to play by the rules when they can easily travel to Hong Kong, Singapore or Japan with a USB stick of bitcoins and either pay with them as currency or exchange those into dollars? The data shared with the Russian authorities is also known to find its way into DarkNet which makes it even less likely that the Russian cryptocurrency owners will be willing to share information on their cryptocurrency holdings with the Russian authorities [9].
Another question is that the Law seems to apply only to the issuances of cryptocurrency falling under the Russian domain zone with equipment located on the territory of the Russian Federation, or those made with the use of the objects of the Russian information infrastructure [7]. Even if we overlook the ambiguity of the above provisions, if one

TABLE 1. TREATMENT OF CRYPTOCURRENCIES IN DIFFERENT COUNTRIES [10].

\begin{tabular}{|c|c|}
\hline Country & Treatment of Cryptocurrencies \\
\hline Japan & Means of payment \\
\hline Philippines & Means of payment \\
\hline Sweden & Means of payment \\
\hline New Zealand & Payment system \\
\hline Argentina & Money (but not legal currency) \\
\hline Australia & Money \\
\hline Germany & Unit of account and private money \\
\hline Brazil & Asset \\
\hline Canada & Asset \\
\hline Finland & Asset \\
\hline Israel & Asset \\
\hline Mexico & Asset \\
\hline The Netherlands & Asset \\
\hline Norway & Asset \\
\hline Russia & Asset \\
\hline Hong Kong & Commodity \\
\hline Pakistan & Commodity \\
\hline The United States & $\begin{array}{l}\text { Commodity, security, } \\
\text { currency/form of money, asset } \\
\text { (depending on the regulator, } \\
\text { legal regime and particular } \\
\text { crypto) }\end{array}$ \\
\hline The United Kingdom & No settled approach \\
\hline Bolivia & Banned \\
\hline Ecuador & Banned \\
\hline Iceland & Banned \\
\hline Nigeria & Banned \\
\hline Romania & Banned \\
\hline Vietnam & Banned \\
\hline
\end{tabular}

would want to avoid Russian jurisdiction one can easily use computing power of the equipment outside Russia. For instance, cloud mining - a mechanism to mine a cryptocurrency, using rented cloud computing power and without having to install and directly run the hardware and related software [14] - is gaining popularity in the world with Russia being on the forefront of that trend. According to the 2019 Mining Industry Annual Research Report " $[t]$ he 'blue ocean' market for cloud mining is outside of China" with a "staggering" number of users in Russia [21]. SimilarWeb data suggest that in 2019 Russia had the largest number of the monthly unique cloud mining users in the world (see Figure 1). It is, thus, clear that anyone who will take the trouble can easily evade the law and the Russian jurisdiction. 


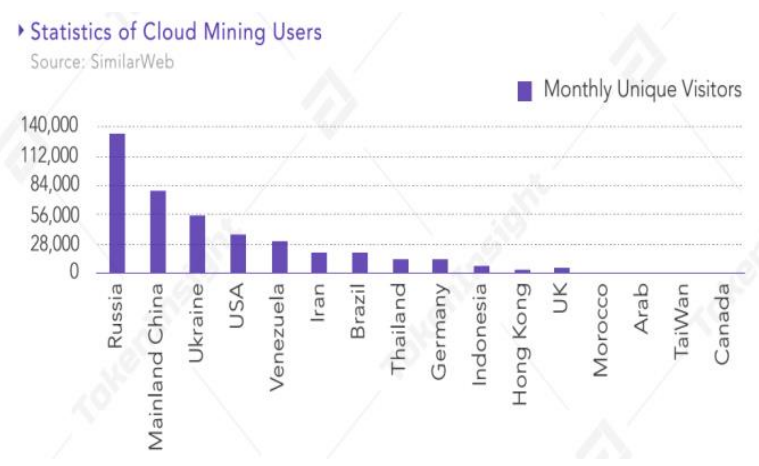

Fig. 1. Monthly unique cloud mining users statistics for year 2019 [21].

The Law is also silent on the definition and regulatory framework for mining, perhaps one of the key issues for such major distributor of Bitcoin network hashrate as Russia (ranks $4^{\text {th }}$ place after China, Canada and the USA) (see Figure 2).

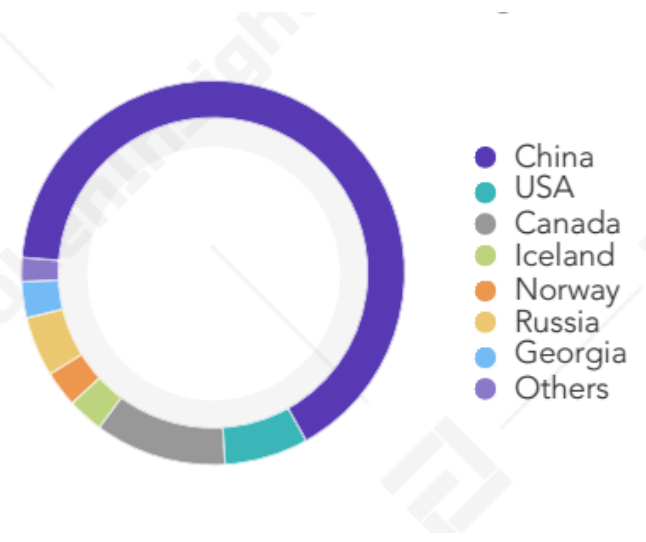

Fig. 2. Geographical distribution of Bitcoin computing power [21].

Since the Law clearly does not cover all aspects of cryptocurrency regulation it is expected that the Law will further be complemented by the federal law "On Digital Currency" which will elaborate in more detail on regulation relating to cryptocurrency and mining. In the interim, the Ministry of Finance announced on 12 November 2020 that in light of the Law entering into force on 1 January 2020, it prepared certain revisions to the Tax Code, Code of the Administrative Offences and Criminal Code (the "Draft Bills") [17] to prevent the illegal use of cryptocurrencies. In order to achieve this incentive, the Ministry of Finance suggested that identification, declaring cryptocurrency as well as of the owners of such assets. We will discuss whether such proposal is likely to meet the declared incentive below.

\section{LIABILITY FOR FAILURE TO COMPLY WITH THE LAW}

The Draft Bills suggests that for tax and criminal law purposes cryptocurrency is an asset. It also provides for the following obligations of the cryptocurrency and DFA holders and liability for breach of the same:

\section{a. Tax Liability:}

i. Holders of cryptocurrencies have to inform the tax authorities in the electronic form about having received the right to dispose of cryptocurrency, provide a report on the operations with cryptocurrencies and on the remainder of the cryptocurrencies in the wallet, if the amount of cryptocurrency debited or credited within one calendar year exceeds equivalent to 600,000 rubles (approx. USD $7,900)$. This sum is calculated based on the market price of the cryptocurrency at the date of the relevant operations.

The September proposal of the Ministry of Finance envisaged reporting for transactions and holdings amounting to 100,000 rubles (approx. USD 1,300), hence this is a significant increase of a reporting threshold. The first reporting deadline will be 30 April 2022.

ii. Failure to inform the tax authorities of the events item 3.1.1 may result in a fine of 50,000 rubles (approx. USD 660).

iii. Failure to include profits from operations with cryptocurrencies into the taxable income (and the resulting failure to pay tax on such amounts) may result in a fine of up to $40 \%$ of the amount of the unpaid tax [4].

\section{b. Criminal Liability:}

i. Systemic failure (for two or more reporting periods) to report the operations with cryptocurrencies or knowingly including false information into the report, with respect to the amount exceeding 15,000,000 (approx. USD 198,000) within the 3 -year period is punishable by:

1. a fine of 100,000-300,000 rubles (approx. USD 1,300-4,000); or

2. a fine in the amount of the 1-2-year wage or income; or

3. compulsory labor for up to 2 years with debarment from holding certain positions or prohibition to engage in certain activities for up to 3 years or without such; or

4. apprehension for a period of up to six months with debarment from holding certain positions or prohibition to engage in certain activities for up to 3 years or without such.

ii. The fines above and the length of sentences increases, if the relevant crimes:

1. include the amount exceeding $15,000,000$ rubles (approx. USD 198,000) (large scale), or 45,000,000 rubles (approx. USD 600,000) (especially large scale), in each case that the relevant person could dispose of within the 3year period; or

2. are committed:

a. by a group of persons;

b. are committed upon a preliminary collusion;

c. are committed with the use of the document known to be forged; or

d. are committed with the use of a legal person specifically created to commit one or several financial crimes [4].

\section{c. Administrative liability:}

i. The Draft Law further provides for administrative liability for accepting cryptocurrency or DFAs as means of payment for the transferred goods or services. Such liability varies depending on who accepts the relevant cryptocurrency or DFAs: 
1. For individuals - an administrative fine of 20,000 to 200,000 rubles (approx. USD 260-2,600) is imposed along with the confiscation of the cryptocurrency o DFAs in question.

2. For officers - an administrative fine of 50,000 to 400,000 rubles (approx. USD 660-5,300) is imposed along with the confiscation of the cryptocurrency of DFAs in question.

3. For legal persons - an administrative fine of 100,000 to $1,000,000$ rubles (approx. USD 1,300-13,000) is imposed along with the confiscation of the cryptocurrency of DFAs in question.

ii. The law prescribes that operators of information systems need to be included into the register as prescribed by the Law to register issuances or other transactions with the DFAs. The Draft Bills provide that failure to do so may result in fines. Interestingly, the Draft Bills expand the scope of the administrative liability on the DFAs issued in the information systems organized under the foreign law which demonstrates the extraterritorial effect of the Law [3].

The Ministry of Finance claims that the incentive behind the tough regulations was to prevent the use of cryptocurrencies for illegal purposes, specifically money laundering transactions [21]. In our view, the requirement to report on the operations with cryptocurrencies is overall reasonable for the purposes of tax liability. However, a number of experts agree that criminal liability is a somewhat excessive measure unproportionate to the deed itself (See e.g. opinion of Yuriy Pripachkin, Head of the Russian Association in of Cryptoeconomics, Artificial Intelligence and Blockchain in [11]). Indeed, Russian taxpayers have similar liability to report to the Russian tax services on the accounts that they hold in the foreign banks, however, failure to meet such requirement results only in fines and community service. In certain circumstances, criminal case may be brought in case of failure to pay taxes but not for failure by the taxpayer to notify the tax services about the transactions with assets or currency. That said, harsh liability for operations with cryptocurrency is somewhat surprising. Such legislative initiative could be explained by increase of crimes involving cryptocurrency and interest of the state in controlling the digital sector (See opinion of Aleksey Dobrinin, Managing Partner of the Bar Association Pen \& Paper in [11]).

Despite the stir the Draft Bills caused in the legal community, their current versions suggest that they will enter into force simultaneously with the Law, i.e. on 1 January 2021. In our view, given that the Draft Bills were only introduced on 12 November 2021 that certainly leaves insufficient time to receive proper feedback from the legal community and experts. The fear is then that such stern measures will either stall the development of cryptoindustry in Russia or bring it outside the Russian jurisdiction.

\section{PRECEDENT TRANSACTIONS}

Unlike a possibility of criminal liability for failure to report transactions with cryptocurrency, some developments related to cryptocurrency have been more positive. Kommersant reported in November 2019 that bitcoin had been contributed to the charter capital of a limited liability company and such change has been registered by the Russian Tax Service [18]. One of the investors of Limited Liability Company "Artel" contributed 0.1 bitcoins (approx. 60,000 rubles, or USD 940) at the time of the contribution in exchange for a $5 \%$ share in the company. In order to make such contribution, appraising company "Veta" had to conduct independent evaluation of the e-wallet and the act of transfer and acceptance of the e-wallet login and password and other deal documentation were notarized. Hence, even before the enactment of the Law, state authorities were eager to register the cryptocurrency contribution thus inexplicitly acknowledging its legal status as an asset.

The appraiser certainly stepped onto the unchartered territory here agreeing not only to appraise cryptocurrency but even developing its own methodology to do so. The managing partner of "Veta" noted that the key problem with the appraisal process was certainly lack of legal regulation. More guidance from the legislator is expected to increase the demand in cryptocurrency evaluation in the future [17].

A more recent precedent was a loan issued by Expobank and secured by Waves tokens in August 2020. The loan was issued to Mikhael Uspenskiy (also the CEO of LLC "Artel") with the use of the escrow account mechanics [19]. This precedent opens the door for a possibility of cryptocurrency being used as security in financing deals, being deposited or being used for other similar purposes as an asset. This a huge step that will allow owners of cryptocurrency to actually monetize it [8].

On the other hand, similar transactions will probably not be popular because cryptocurrency is a high-risk asset for the banks with the high volatility and the legislative guidance still lacking [19]. If the banks were to seize collateral on the defaulted loan, the question is how the banks will navigate the regulations on cryptocurrency and tokens when investing or disposing of them and record the same in the books.

While many acknowledge that the cryptocurrency is volatile, so is the Russian ruble. In fact, it is believed that the weak status of Russia's national currency was a major contributor to the surge of cryptocurrency. According to the data of the crypto firm Paxful in Russia, the platform's crypto peer-to-peer (P2P) trading in Russia surged as high as $350 \%$ on a year-over-year basis [13]. Thus, maybe at some point pledge over cryptocurrency may even be a more preferred option than pledge over the ruble accounts.

While the precedents of cryptocurrency being used in business transaction are certainly encouraging, one should probably not expect any quick progress in use of the cryptocurrencies in the corporate and financing transactions. That said, such precedents open the door to new possibilities of a wider use of cryptocurrency in structuring business transactions [9].

\section{Digital RUBLE}

On 13 October 2020 the Central Bank of Russia announced its plans to run an experiment with a central bank digital currency (CBDC) with a limited number of participants and after public consultations. According to the CBR report, similar to cash and non-cash payments CBDC will have three functions: means of payment, 
measure of value and store of value. All three forms of the Russian ruble will be equivalent and interchangeable: 1 ruble in cash will be equivalent to 1 ruble in cashless settlement and equivalent to 1 ruble in CBDC [2]

Although there are clear parallels between CBDC and cryptocurrency, these are two very different instruments. Cryptocurrencies neither have a single issuer, nor do they provide the consumer rights protection. They can not be used to pay for goods and services in Russia, and as a rule no institution safeguards such assets [1].

CBDC is an obligation of the Russian Central Bank implemented through digital technologies. It is a fiat currency, i.e. currency whose the stability and functionality is guaranteed by the state through the Central Bank [2]. The digital ruble wallet can be used to pay for goods and services in Russian stores where payment terminals are configured to accept it. The Central Bank even suggested that if the digital ruble is adopted, Russians may be able to receive salaries and benefits in it. The State Duma expects the digital ruble experiment to start in the first half of 2021 [15]. In other words, the CBDC is an additional means of non-cash payment and not a cryptocurrency in the classic sense. The main incentive for creating CBDC is reduction in transaction costs and the volume of burden on banks, an increase in cross-border payments, as well as a decrease in dependence on the dollar and exposure to sanctions [15]. The Central Bank intends to use CBDC, among others, in the remote and underpopulated areas where access to financial infrastructure is limited. This will lead to increase of coverage of the population with financial services which will become more accessible [2].

\section{CONCLUSION}

Russia is currently one of the biggest players in the cryptocurrency market, thus having clear rules on cryptocurrencies is important for all actors active on the Russian market and those using Russian information infrastructure. The country is finally headed in the direction of legal clarity in regulation of cryptocurrencies. This is certainly a welcome development but the adoption of the comprehensive regulatory framework has not been completed pending the presentment and approval of the federal law "On Digital Currency". It is, however, clear that a start has been made with the adoption of the Law.

The main concern for the development of the industry in the future is certainly overinvolvement of the Central Bank, RosFinMonitoring and the Ministry of Finance as well as overregulation and harsh penalties for failure to comply with certain rules. One alarming example of this is the new legislative initiative on criminal liability to be imposed for failure to report operations with cryptocurrencies. We believe that such measure is disproportionate to the deed and may substantially stall the development of the Russian cryptoindustry. On the bright side, we see examples of the cryptocurrency being treated as an asset by the Russian authorities and banks even before the enactment of the relevant laws. We expect the cryptocurrency being widely used in the corporate and financing transactions in the future. It will also be interesting to observe the outcome of the CBDC experiment, although it has little significance for the cryptoindustry as such given that $\mathrm{CBDC}$ is more of a cashless settlement than a cryptocurrency.In conclusion, we note that it is important that legislators and regulators embrace the new reality that cryptocurrency era has already begun. The key question is, will they be able to create such a regulatory regime that projects and investments will come into Russia instead of going into countries with more favourable cryptocurrency regimes?

\section{REFERENCES}

[1] A. Borzova, E. Dorokhova, Prospects for the development of the digital economy in Russia, Scientific research of young scientists: collection of articles of the IV International Scientific and Practical Conference, Penza, 2020, 190 p.

[2] Digital Ruble. Reports for Public Consultations, CBR Website. DOI: https://www.cbr.ru/analytics/d_ok/dig_ruble/.

[3] Draft Bill No. 02/04/10-20/00108949, On Amendments to the Code of the Russian Federation on Administrative Offences. DOI: https://regulation.gov.ru/projects\#npa=108949.

[4] Draft Bill No. 02/04/10-20/00108952, On Amendments to the Criminal Code of the Russian Federation and Article 5 of the Code of Criminal Procedure of the Russian Federation. DOI: https://regulation.gov.ru/projects\#npa=108952.

[5] Draft Bill No. 02/04/10-20/00108960, On Amendments to Parts One and Two of the Tax Code of the Russian Federation. DOI: https://regulation.gov.ru/projects\#npa $=108960$

[6] E. Dorokhov, A. Borzov, Digital Transformation of the Economy: Global Trend and Russian Trends. https://www.amazon.com/ /dp/6202684275 (accessed 27.07.2020).

[7] E. Dorokhov, A. Borzov, "Evaluation of the penetration of digital technologies into the business of Russian and foreign companies", Economics and Entrepreneurship, No. 8, 2020, pp. 54-58.

[8] E. Dorokhov, E. Klecina, "Electronic budget as a tool of digital technologies: international experience", Microeconomics. Economics and Entrepreneurship, No. 8, 2020, pp. 54-58.

[9] E. Dorokhova, L. Konshina, Opportunities and Prospects for the Development of Cryptocurrencies in the Russian Federation, Actual Problems of the Economy of modern Russia: collection of scientific papers of the All-Russian (National) scientific and practical conference, Yoshkar-Ola, Yoshkar-Ola, Issue 6, 2019, 286 p.

[10] E. Dorokhova, P. Lyadnova, H. Whitney, "Cryptocurrencies in Insolvency: Evasive Reality”, Emerging Markets Restructuring Journal, 7, 2018, pp. 22. DOI: https://www.clearygottlieb.com//media/files/emrj-materials/issue-7-summer-2018/cryptocurrencies -in-insolvency--evasive-reality-pdf.pdf.

[11] E. Tschernishova, Y. Starostina, MinFin Proposed to Imprison for Failure to Declare Cryptocurrencies. What Information Must Holders of Such Assets Provide to the Tax Officers, RBC Finances. DOI: https://www.rbc.ru/finances/12/11/2020/5fac09a99a794793 ec51f92b.

[12] Federal Law 259-FZ “On Digital Financial Assets, Cryptocurrency and Making Changes to Certain Legislative Acts of the Russian Federation". URL: http://www.consultant.ru/document/cons_ doc_LAW_358753/ (accessed 31.07.2020).

[13] H. Partz, Russia's Crypto Law Is a Mixed Bag, According to Industry Execs, Cointelegraph. DOI: https://cointelegraph.com/news/russias-crypto-law-is-a-mixed-bag-according-to-industry-execsю

[14] J. Frankenfield, Cryptocurrency Strategy \& Education: Cloud Mining. DOI: https://www.investopedia.com/terms/c/cloudmining.asp.

[15] K. Helms, Digital Ruble: Russia Unveils Plans to Test Central Bank Digital Currency, Bitcoin.Com. DOI: https://news.bitcoin.com/digital-ruble-russia-central-bank-digitalcurrency/

[16] M. Tetkin, A loan secured by cryptocurrency has been officially issued in Russia, For the first time, RBC Regulation, DOI: https://www.rbc.ru/crypto/news/5f3cc67d9a794735358a545e.

[17] Official Website of the Russian Ministry of Finance, Russian Ministry of Finance Developed a Package of Bills on Cryptocurrency, in: Russian Ministry of Finance Press-center. DOI: https://minfin.gov.ru/ru/press-center/?id_4=37278-

[18] P. Smorodskaya, Bitcoin Has Been Contributed Under the Charter, Kommersant 216/P 7. DOI: https://www.kommersant.ru 
$/ \mathrm{doc} / 4170151$

[19] T. Maksimenko, The Law on the Difital Assets: pros and cons. DOI: https://www.if24.ru/zakon-o-tsifrovyh-aktivah-plyusy-i-minusy/

[20] V. Arshinova, Adopted but not really. The Law on the digital financial Assets, LFA Academy. DOI: https://lfacademy.ru/sphere/post/prinyali-no-ne-sovsem-zakon-ocifrovyh-finansovyh-aktivah.

[21] Mining Industry Annual Research Report, 2019, pp.7-15. DOI: https://image.tokeninsight.com/upload/levelPdf/2019-MiningIndustry-Annual-Research-Report.pdf 